CONCISE REPORT

\title{
Relationship between serum hyaluronic acid level and disease activity in early rheumatoid arthritis
}

\author{
M Majeed, F McQueen, S Yeoman, L McLean
}

Ann Rheum Dis 2004;63:1 166-1168. doi: 10.1136/ard.2003.010942

\begin{abstract}
Objectives: To measure hyaluronic acid (HA) levels, which are raised in active rheumatoid arthritis (RA), in patients with early RA, and to assess the correlation with clinical and laboratory indices of disease activity and with subsequent radiographic erosive status.

Patients and methods: Patients fulfilling ACR criteria were recruited into a prospective cohort within 6 months of disease onset and reviewed every 6 months. An HA binding protein based sandwich ELISA was used to measure HA in 240 sera from 82 patients at regular intervals.

Results: Patients had higher HA levels than age matched healthy blood donor controls (median 37.4 v $29.1 \mathrm{ng} / \mathrm{ml}$, respectively, $\mathrm{p}<0.02$ ), which increased with more prolonged disease. Baseline HA level correlated with measures of disease activity, including swollen and tender joint counts, $H A Q$, global assessments, ESR, and CRP; was higher in men; and increased with age. There was no relationship with HLADRB 1 shared epitope or rheumatoid factor status. At 6 and 12 month follow up visits, HA levels were higher in patients who later developed erosions. However, a raised HA level was not a good predictor of erosions.

Conclusions: Serum HA level correlates with clinical and laboratory measures of disease activity in early RA, but is unlikely to be of practical use in clinical practice.
\end{abstract}

$\mathrm{T}$ he timely introduction of effective disease modifying antirheumatic drugs (DMARDs) can help prevent irreversible articular damage in rheumatoid arthritis (RA). New immunomodulatory approaches may offer greater disease suppression but are expensive and may carry significant adverse effects. Prognostic markers that better predict adverse structural and functional outcomes in early RA would best target these regimens, and provide early biomarkers for the response to new treatments.

Hyaluronic acid (HA) is an unbranched polysaccharide chain molecule produced by type B (fibroblast-like) synoviocytes and chondrocytes. In synovial fluid each molecule consists of a long linear polymer of disaccharide $(\mathrm{N}$ acetylglucosamine and glucuronic acid) repeats and in this form it is important for joint lubrication. HA is also a critical cartilage glycosaminoglycan component, binding and retaining multiple aggrecan monomers and tethering these to chondrocytes through the cell surface glycoprotein CD44. Raised serum levels of HA have previously been noted in RA. The HA level has been reported to correlate with indices of joint inflammation, and may have some specificity for synovial inflammation. It has been suggested that a raised HA level early in disease may also predict future joint destruction..$^{2-8}$ We examined this in a group of patients with early RA (mean symptom duration at baseline 4 months).

\section{PATIENTS AND METHODS}

\section{Patients and controls}

The patients were part of a prospective cohort of 126 patients with new onset RA recruited between 1995 and 1997 to study magnetic resonance imaging and HLA-DRB1 genotyping. All patients fulfilled the 1987 American College of Rheumatology (then American Rheumatism Association) criteria for RA and had symptoms of 6 months' or less duration at the time of recruitment. Clinical, laboratory, radiographic, and immunogenetic assessments have been described previously. ${ }^{9-11}$ Briefly, demographic and clinical data at baseline included median onset age 46 years; symptom duration 4 months; female 67\%; rheumatoid factor seropositive $81 \%$; $51 \%$ taking a DMARD; $20 \%$ taking low dose ( $\leqslant 10 \mathrm{mg}$ /day) prednisone; swollen joints 13/66; tender joints 25/68; pain visual analogue scale (VAS) 28/100; Health Assessment Questionnaire (HAQ) 0.6 ; erythrocyte sedimentation rate (ESR) $27 \mathrm{~mm} / \mathrm{lst} \mathrm{h}$; and $\mathrm{C}$ reactive protein $(\mathrm{CRP}) 11 \mathrm{mg} / \mathrm{l}$.

In addition to comparison with the manufacturer's reference samples (below) and upper limit of normal, 47 healthy age matched blood donor volunteers acted as controls. The control subjects completed standard blood donor health questionnaires but were not assessed clinically and did not have acute phase or immunogenetic studies. All samples were taken in an ambulant outpatient setting using the same venepuncture technique from the antecubital fossa with a brachial tourniquet and put into gel activated serum separation tubes; most samples were taken during the morning. However, no attempt was made to standardise recent physical activity including weight bearing or ambulation before the clinic visit, nor did we stratify for sample collection time.

\section{Hyaluronic acid assay}

HA levels were measured in triplicate with a commercial enzyme linked immunosorbent assay (ELISA) kit (Chugai/ Reads Medical Products, Westminster CO) according to the manufacturer's instructions. This sandwich assay uses HA binding protein (HABP) as the immobilised capture phase for HA in the subject's serum sample, followed by the addition of serum, peroxidase linked HABP, then substrate. We assayed 240 sera from 83 patients: 77 samples at baseline, 49 samples at 6 months, 54 samples at 1 year, 39 samples at 18 months, and 21 samples at the 2 year follow up, depending on the availability of archived samples.

Abbreviations: CRP, C reactive protein; DMARD, disease modifying antirheumatic drug; ELISA, enzyme linked immunosorbent assay; ESR, erythrocyte sedimentation rate; $\mathrm{HA}$, hyaluronic acid; HABP, hyaluronic acid binding protein; $H A Q$, Health Assessment Questionnaire; RA, rheumatoid arthritis; RF, IgM rheumatoid factor; SE, HLA-DRB1 shared epitope; VAS, visual analogue scale 


\section{Analysis}

Triplicate reference standards with HA at $10-800 \mathrm{ng} / \mathrm{ml}$ were included on each plate for the standard curve, together with the one patient's serum as an internal quality control for interassay reproducibility. Subjects' HA levels were interpolated from the standard curve using third order polynomial regression (PRISM version 4.00, GraphPad Software, San Diego, CA). Differences between groups were tested by the Mann-Whitney test for independent samples, and correlations were calculated using the Spearman coefficient.

\section{RESULTS}

\section{Hyaluronic acid levels}

The HABP based ELISA for HA performed well, with mean interassay and intra-assay coefficients of variation of $8.7 \%$ and $2.7 \%$, respectively. The manufacturers' "normal range" was quoted as $<100 \mathrm{ng} / \mathrm{ml}$; alternatively, we used a locally derived cut off point of $60 \mathrm{ng} / \mathrm{ml}$, based on the control subjects' mean plus two standard deviations. One patient had an HA level two orders of magnitude higher on four occasions $(3198,494,318$, and $2808 \mathrm{ng} / \mathrm{ml})$; this subject's values were excluded from the final analysis.

Patients with early RA had higher HA levels than controls (median levels $37.4 v 29.1 \mathrm{ng} / \mathrm{ml}$, respectively, $\mathrm{p}<0.02$ ), but this difference was less marked at baseline than at later assessments (table 1), the rises at individual times achieving statistical significance at 1 and 2 years only. HA levels were higher in male than in female patients (table 1) and correlated weakly with increasing age (patients with RA, Spearman $r_{\mathrm{s}}=0.276, \mathrm{p}=0.015$; controls, $r_{\mathrm{s}}=0.41$, $p=0.070)$. No significant difference was found in HA level between RF seropositive and seronegative patients, or between those with and those without the HLA-DRB1 shared epitope sequence, which is associated with severity (table 1).

Table 1 Serum hyaluronic acid levels according to follow up time, rheumatoid factor, and shared epitope, and 1 and 2 year radiographic erosion status

\begin{tabular}{|c|c|c|}
\hline & $\begin{array}{l}\text { Hyaluronic acid }(\mathrm{ng} / \mathrm{ml}) \\
\text { Median }(25-75 \% \text { IQR) }\end{array}$ & p Value \\
\hline Control sera & $29.1(19.7-40.7)$ & \\
\hline $\begin{array}{l}\text { RA sera, pooled time points } \\
\text { Baseline }\left(n=77^{*}\right) \\
6 \text { Months }(n=49) \\
1 \text { Year }(n=54) \\
18 \text { Months }(n=39) \\
2 \text { Years }(n=21)\end{array}$ & $37.4(21.3-72.9)$ & $\begin{array}{l}0.0199 \dagger \\
0.236 \dagger \\
0.145 \dagger \\
0.027 \dagger \\
0.074 \dagger \\
0.0003 \dagger\end{array}$ \\
\hline Male RA & $50.4(28.1-83.8)$ & \\
\hline Female RA & 32.7 (19.8-69.3) & 0.012 \\
\hline RF seropositive & $34.2(16.3-64.6)$ & \\
\hline RF seronegative & $31.4(22.8-56.8)$ & 0.397 \\
\hline SE positive & $31.6(16.3-64.6)$ & \\
\hline SE negative & $40.8(22.9-56.8)$ & 0.291 \\
\hline Erosive at 1 yearł & $37.1(17.2-70.3) \S$ & \\
\hline Non-erosive at 1 year & $31.8(18.3-46.7) \S$ & 0.530 \\
\hline Erosive at 2 years $\ddagger$ & $39.4(22.9-64.6) \S$ & \\
\hline Non-erosive at 2 years & $26.1(17.4-52.1) \S$ & 0.190 \\
\hline \multicolumn{3}{|c|}{$\begin{array}{l}\text { IQR, interquartile (25th-75th centiles) range; RF, IgM rheumatoid factor; } \\
\text { SE, shared epitope (HLA-DRB1 exon } 2 \text { sequence coding for amino acids } \\
\text { QKRAA, QRRAA or RRRAA at DR } \beta \text { chain positions } 70-74 \text {, by dye- } \\
\text { terminator sequence based typing). } \\
\text { *Sample numbers available at time of study; tp value versus baseline HA } \\
\text { level. All p values two tailed; tradiographic data unavailable from one } \\
\text { patient (HA level excluded from erosion analysis) owing to pregnancy at } \\
\text { both follow up radiology assessments; } \$ \text { HA levels at study baseline. }\end{array}$} \\
\hline
\end{tabular}

\section{Relation to disease activity and outcomes}

Baseline HA level correlated with measures of disease activity including swollen joint count $\left(r_{\mathrm{s}}=0.237, \mathrm{p}=0.0002\right)$, tender joint count $\left(r_{\mathrm{s}}=0.153, \mathrm{p}=0.017\right)$, Ritchie index $\left(r_{\mathrm{s}}=0.215\right.$, $\mathrm{p}=0.0007), \operatorname{HAQ}\left(r_{\mathrm{s}}=0.179, \mathrm{p}=0.005\right)$, pain VAS $\left(r_{\mathrm{s}}=\right.$ $0.185, \mathrm{p}=0.004)$, patient global assessment $\left(r_{\mathrm{s}}=0.254\right.$, $\mathrm{p}<0.0001)$, physician global assessment $\left(r_{\mathrm{s}}=0.250, \mathrm{p}=\right.$ $0.0001)$, ESR $\left(r_{\mathrm{s}}=0.436, \mathrm{p}<0.0001\right)$, and CRP $\left(r_{\mathrm{s}}=0.422\right.$, $\mathrm{p}<0.0001)$.

Overall, serum HA levels considered at all times were higher in the erosive than the non-erosive group $(p=0.049)$. Patients with erosions at the 1 year follow up had higher serum HA levels at 6 months (erosive $44.8 \mathrm{ng} / \mathrm{ml} v$ nonerosive $28.1 \mathrm{ng} / \mathrm{ml}(\mathrm{p}=0.0187))$. Patients with erosions at 2 years had higher serum HA levels at $6(57.3 \vee 26.8 \mathrm{ng} / \mathrm{ml}$ $(\mathrm{p}=0.0015))$ and at 12 months $(57.5 \quad v \quad 21.9 \mathrm{ng} / \mathrm{ml}$ $(p=0.0086))$. However, the baseline HA level was not significantly raised in patients with subsequent erosions after the 1 or 2 year follow up ( $p=0.53,0.19$, respectively).

With a definition of "raised" HA using the manufacturer's upper limit of normal of $100 \mathrm{ng} / \mathrm{ml}$, test sensitivity for erosions at the 2 year follow up was $22.8 \%$, specificity $89.5 \%$, positive predictive value $71.5 \%$, and negative predictive value $50.8 \%$; using the locally derived cut off point of $60 \mathrm{ng} / \mathrm{ml}$, the corresponding test performance values were $40.6 \%, 77.1 \%$, $66.7 \%$, and $53.5 \%$, respectively.

\section{DISCUSSION}

This study used an HABP based sandwich ELISA to show that serum HA level is raised in patients with early RA and correlates with clinical and laboratory measures of disease activity. However, the rise in HA in our patients was not as dramatic as previously reported. ${ }^{25} 6$ This may reflect the shorter disease duration of our cohort and the contemporary trend towards more aggressive early treatment, as the mass of inflamed synovial tissue has been found to correlate with HA level. ${ }^{2}$

There are conflicting previous reports on the correlation between HA level and CRP and ESR, ${ }^{25}{ }^{2}$ found to be substantial in this study. This may in part reflect differences in patient selection and treatment. In one study HA level tended to correlate with these two markers at study entry, but with the institution of drug treatment the correlation was lost, as the HA level continued to be raised while the levels of other markers of inflammation decreased. ${ }^{6}$

The HA level is reported to change in response to physical activity, and along with other biomarkers related to matrix turnover it shows significant diurnal variation. ${ }^{12}$ All samples were taken in an ambulant outpatient setting using the same venepuncture technique from the antecubital fossa with a brachial tourniquet and put into gel activated serum separation tubes, and most samples were taken during the morning. As no attempt was made to standardise recent physical activity, including weight bearing or ambulation, before the clinic visit, and we did not stratify for sample collection time, it is possible that additional variability introduced might have obscured a stronger relationship with disease activity and outcome measures.

Although statistically significant, the correlations between serum HA level and clinical indices of disease activity were relatively weak (all $r_{\mathrm{s}}<0.3$ ). The strongest correlations were with other laboratory indices of disease activity (ESR, $\left.r_{\mathrm{s}}=0.436 ; \mathrm{CRP}, r_{\mathrm{s}}=0.422\right)$ rather than clinical.

As HA is synthesised by synoviocytes and is also a prominent component of articular cartilage, an increased systemic level might act as an early indicator of structural damage and hence provide a useful prognostic marker. ${ }^{5}$ Although we found that erosive disease was associated with raised HA levels at some times, this was not the case for 
baseline levels which would be of most relevance for making an early decision on aggressive treatment. Moreover, neither of the cut off levels used provided particularly attractive sensitivity, specificity, or predictive value for use as a practical diagnostic test. Similarly, Fex and colleagues found that although baseline HA levels correlated with follow up radiography, they did not add to the predictive value of baseline ESR. $^{7}$

One patient showed very high HA levels. This 58 year old female patient was seronegative for rheumatoid factor, HLADRBl shared epitope negative, erosive at the 2 but not at the 1 year follow up and had normal liver function tests. Paimela and colleagues also noted unusually high levels of HA (1284 and $2456 \mathrm{ng} / \mathrm{ml}$ ) in one of 40 patients with RA studied, ${ }^{5}$ but as in our study could not attribute this to any particular clinical feature. Although HA is most abundant in articular tissues, it is widely distributed, ${ }^{13}$ and raised HA has been detected in several other diseases. ${ }^{14}$

In summary, although the serum level of HA is raised in RA and shows some relation with disease activity, the information this adds to standard measures is little.

\section{ACKNOWLEDGEMENTS}

The HA ELISA kits were supplied by AMRAD Pharmacia, Australia. Funding support for the Auckland Early RA study came from the Arthritis Foundation of New Zealand, the Auckland Medical Research Foundation, the Health Research Council, and Lotteries Health.

\section{Authors' affiliations}

M Majeed, F McQueen, S Yeoman, L Mclean, Department of Molecular Medicine, University of Auckland, Private Bag 92019, Auckland 1001, New Zealand

Present Address: Dr M Majeed, Department of Medicine, John Stroger Hospital of Cook County, Chicago, IL 60612, United States of America

Correspondence to: Dr L McLean, AstraZeneca R\&D Charnwood, Loughborough, Leicestershire LE1 1 5RH, UK; lachy.mclean@ astrazeneca.com

Accepted 21 October 2003

\section{REFERENCES}

1 van der Heide A, Jacobs J, Biilsma J, Heurkens AH, van Booma-Frankfort C, van der Veen MJ, et al. The effectiveness of early treatment with "second-line" antirheumatic drugs. A randomized, controlled trial. Ann Intern Med 1996; 124:699-707.

2 Engstrom-Laurent A, Hallgren R. Circulating hyaluronate in rheumatoid arthritis: relationship to inflammatory activity and the effect of corticosteroid therapy. Ann Rheum Dis 1985;44:83-8.

3 Horslev-Petersen K, Bentsen KD, Engstrom-Laurent A, Junker $P$, Halberg $P$, Lorenzen I. Serum amino terminal type III procollagen peptide and serum hyaluronan in rheumatoid arthritis: relation to clinical and serological parameters of inflammation during 8 and 24 months' treatment with levamisole, penicillamine, or azathioprine. Ann Rheum Dis 1988;47:116-26.

4 Poole AR, Witter J, Roberts N, Piccolo F, Brandt R, Paquin J, et al. Inflammation and cartilage metabolism in rheumatoid arthritis. Studies of the blood markers hyaluronic acid, orosomucoid, and keratan sulfate. Arthritis Rheum 1990;33:790-9.

5 Paimela L, Heiskanen A, Kurki P, Helve T, Leirisalo-Repo M. Serum hyaluronate level as a predictor of radiologic progression in early rheumatoid arthritis. Arthritis Rheum 1991;34:815-21.

6 Emlen W, Niebur J, Flanders G, Rutledge J. Measurement of serum hyaluronic acid in patients with rheumatoid arthritis: correlation with disease activity. J Rheumatol 1996;23:974-8.

7 Fex E, Eberhardt K, Saxne T. Tissue-derived macromolecules and markers of inflammation in serum in early rheumatoid arthritis: relationship to development of joint destruction in hands and feet. Br J Rheumato 1997:36:1161-5.

8 Garnero G, Rousseau J-G, Delmas PD. Molecular basis and clinical use of biochemical markers of bone, cartilage, and synovium in joint diseases. Arthritis Rheum 2000;43:953-68.

9 McQueen FM, Stewart N, Crabbe J, Robinson E, Yeoman S, Tan PL, et al. Magnetic resonance imaging of the wrist in early rheumatoid arthritis reveals a high prevalence of erosions at four months after symptom onset. Ann Rheum Dis 1998;57:350-6.

10 McQueen FM, Stewart N, Crabbe J, Robinson E, Yeoman S, Tan PL, et al. Magnetic resonance imaging of the wrist in early rheumatoid arthritis reveals progression of erosions despite clinical improvement. Ann Rheum Dis 1999;58:156-63.

11 McQueen F, Benton N, Perry D, Crabbe J, Robinson E, Yeoman S, et al. Bone oedema scored on magnetic resonance scans of the dominant carpus at presentation predicts radiographic joint damage at the hands and feet six years later in patients with rheumatoid arthritis. Arthritis Rheum 2003;48: 1814-27.

12 Manicourt DH, Poilvache P, Nzeusseu A, van Egeren A, Devogelaer JP, Lenz ME, et al. Serum levels of hyaluronan, antigenic keratan sulfate, matrix metalloproteinase 3, and tissue inhibitor of metalloproteinases 1 change predictably in rheumatoid arthritis patients who have begun activity after a night of bed rest. Arthritis Rheum 1999;42:1861-9.

13 Hardingham T. Proteoglycans: their structure, interactions and molecular organization in cartilage. Biochem Soc Trans 1981;9:489-97.

14 Engstrom-Laurent A, Loof L, Nyberg A, Schroder T. Increased serum levels of hyaluronate in liver disease. Hepatology 1985;5:638-42. 